\title{
УДК: 371.68:004.428:373.5.016:5
}

Савченко Зоя Вячеславівна, науковий співробітник Інституту інформаційних технологій і засобів навчання Академії педагогічних наук України.

\section{ОСНОВНІ ВИМОГИ ДО НАВЧАЛЬНИХ КОМП'ЮТЕРНИХ ПРОГРАМ У БАЗОВІЙ СЕРЕДНІЙ ОСВІТІ}

\section{Анотація}

Стаття присвячена актуальним питанням ефективності використання навчальних комп'ютерних програм (НКП) в комп'ютерно орієнтованому навчальному середовищі, вказані основні вимоги до них та поданий перелік сертифікованих розробок НКП із природничих предметів, які можна пропонувати для базової середньої освіти.

Ключові слова: навчальні комп'ютерні програми, педагогічні програмні засоби, сертифіковані програмні розробки.

Використання комп’ютерних технологій у загальноосвітніх навчальних закладах $є$ важливим i актуальним питанням для сучасної освіти, яка відкриває можливості не тільки для оптимізації навчання, використання нових форм і методів проведення уроків, а й підвищення мотивації учнів до навчання. Інформаційні й комунікаційні технології дозволяють підняти якісний рівень аудиторних (лекційних та лабораторних), аудиторно-самостійних та самостійних занять. Нині в освіті використовується найчастіше програмне забезпечення загального призначення, а саме: текстові редактори, електронні таблиці, графічні редактори тощо.

Метою статті є дослідити існуючі розробки навчальних комп'ютерних програм, педагогічних програмних засобах навчання їх відповідності Закону про освіту, Державним стандартам базової освіти та іншим нормативним правовим документам 3 подальшим наданням рекомендацій щодо їх використання в ЗНЗ.

Кожен ППЗ є результатом творчості авторів, через що має власні неповторні якості, власну структуру, оформлення, естетику, функціональні можливості, зміст, способи і форми подання навчальної інформації тощо. Результатом різноманітності підходів, строкатості спектру авторських задумок та методів їх реалізації є різноманітність підходів до способів використання комп'ютерно орієнтованих засобів навчальної діяльності в навчально-виховному процесі [10].

На думку багатьох як українських, так і російських дослідників (Бронштейн Є.М., Гареєва Л.Р., Закірова Г.Ф, Козлов О.А., Солодова Є.А., Холодов Є.Н., Моргун О.М., Підласий А.І., Машбиць Є.І.) [1-4] необхідно застосовувати спеціалізовані навчальні системи тому, що це дозволить підвищити ефективність навчального процесу. Водночас $є$ велика кількість різних підходів до класифікації навчальних комп'ютерних програм (НКП), але немає єдиної думки та відповідно й загальної класифікації [4], що ускладнює процес контролю та сертифікацію цих засобів навчання. С.І. Машбиць пропонує таких п’ять типів НКП: а) тренувальні; б) тьюторські; в) проблемного навчання; г) імітаційні та моделюючі; д) ігрові [4].

Однією із форм НКП є електронний підручник, що, залежно від можливостей, які надаються у ньому, може належати до різних типів НКП. На нашу думку, слід погодитися з авторами (Євреінов Є.В., Каймин В.А. [5]), які вважають, що підручник повинен перевіряти засвоєні знання та пропонувати нову порцію інформації тільки після уже засвоєного попереднього матеріалу .

Цікавим досвідом $є$ практика використання НКП в аграрних освітніх закладах України [http://www.sau.sumy.ua/elbooks/EL_POS.doc]. Так, у Дидактичних та технологічних вимогах до 
програми-оболонки для підготовки та використання електронних навчальних посібників [6], зазначається, що основні вимоги до електронних підручників та навчальних посібників можна, у першу чергу, визначити такі вимоги:

- основна функція - викладення теоретичного матеріалу з можливістю контролю за його засвоєнням;

- у вступній частині повинно бути наведено докладні інструкції з вивчення матеріалу й організації самостійної роботи;

- зміст повинен бути складений таким чином, щоб мінімізувати труднощі під час сприйняття та осмислення представленої інформації;

- навчальний матеріал у посібнику підручнику) доцільно структурувати за модульним принципом та подавати окремими «порціями» (дозами), (дидактичні вимоги щодо правил «дозування» матеріалу буде наведено далі);

- навчальний матеріал може подаватись у вигляді тексту і супроводжуватись рисунками та відеофрагментами;

- для закріплення теоретичного матеріалу додатково можуть подаватись приклади виконання розрахунків та розв'язання задач;

- мережеві варіанти посібників можуть містити «мітки» (посилання) на навчальні курси, які вивчались раніше, довідкові матеріали чи окремі статті, які деталізують матеріал, що вивчається;

- після кожної «порції» та модуля обов'язковими елементами повинні бути тести, контрольні завдання, запитання для самоперевірки з відповідями, тренувальні завдання.

Таким чином, структура електронного підручника (посібника) з дисципліни (навчального курсу) незалежно від його змісту повинна містити такі розділи:

- вступ до дисципліни (історія, предмет, актуальність, місце і взаємозв'язок $з$ іншими дисциплінами програми за фахом);

- навчальну програму з дисципліни;

- мету і задачі вивчення дисципліни;

- методичні вказівки щодо самостійного вивчення дисципліни та роз'яснення структури, принципу побудови та використання підручника, порядок організації взаємодії з викладачем;

- зміст підручника;

- викладення матеріалу (основний зміст), структурованого за модулями (розділами) та окремими «дозами»;

- тести, запитання, задачі з відповідями для тренінгу (після кожної дози, розділу, модуля);

- підсумковий тест;

- практичні завдання для самостійної роботи;

- словник термінів;

- список скорочень і абревіатур;

- висновки (за необхідності);

- список літератури (основної, додаткової, факультативної) та посилань на електронні ресурси;

- як додатковий матеріал можуть включатись статті з наукових і періодичних видань, довідкові матеріали, «мітки» (посилання) на інші електронні видання, сайти фірм-виробників і т. д.;

- під час роботи з підручником через Інтернет мережу повинні забезпечуватись функції ідентифікації користувача. 
До навчальних комп’ютерних програм (НКП) освітньо-кваліфікаційного рівня відносяться програмно-методичні комплекси (ПМК), педагогічні програмні засоби (ППЗ), електронні навчальні курси та електронні посібники, електронні атласи, бази знань та енциклопедії, навчальні програмні комплекси, програмні середовища та ін. Такий широкий аспект назв комп’ютерних програм постійно доповнюється все новими назвами . Але всіх їх об'єднує єдина ціль - усе це засоби безпосереднього використання у навчальному процесі. До споживачів таких розробок, у першу чергу, відносяться викладачі вищих навчальних закладів та вчителі середніх шкіл. Це, певною мірою, можна вважати доказом доцільності використання НКП, ППЗ в межах комп'ютерно-орієнтованого навчального процесу [7].

Щоб розібратися в загалі таких розробок, їх слід розглядати в аспекті відповідності Закону про освіту, Закону про мову, Державним стандартам базової освіти [9], навчальним програмам та іншим нормативним правовим документам. Вони повинні задовольняти чинні санітарно-гігієнічні, психофізіологічні та інші вимоги.

Розглянемо НКП, розроблені для загальноосвітніх навчальних закладів, схвалені Науковометодичною комісією ЗН та шкільного обладнання з питань МОН України станом на 2007 рік, що мають Гриф МОН України згідно з Положенням про порядок організації та проведення апробації електронних засобів навчального призначення для загальноосвітніх навчальних закладів від 21.06.2004 p. за № 757/9356 [http://www.mon.gov.ua/laws/MON_433.doc].

До такого переліку відносяться біля 150 розробок, які виконані на замовлення та кошти держави, а також розробки недержавних організацій. На основі цих розробок нами створена база даних, яка дає можливість оперативно аналізувати та вибирати необхідні НКП за освітніми галузями, що затверджені Державним стандартом базової і повної середньої освіти [9]. База сформована у табличній формі, де подано назву навчальної комп'ютерної програми, класи - 31 до 11, рік видання та отримання Грифу МОН України, а також розробника НКП.

Аналізуючи НКП даного сертифікованого списку, можна зауважити про недостатній перелік програмно-методичних засобів розвивальних і навчальних ігор для дітей молодшого шкільного віку ( це лише ППЗ «Музичне мистецтво 1-4 класи» та «Природознавство», «Я і Україна» для 3 та 4 класів). Як доводить практика, такий попит в програмному забезпеченні здійснюється переважно стихійно, і за рахунок «піратських» розробок та придбання їх на ринку приватно [7].

Математична діяльність у рамках предметної галузі, що вивчається, спирається на використання засобів і методів розв'язування задач з інших (більш елементарних, вивчених, засвоєних раніше) предметних галузей., однак перелік таких розробок не $є$ послідовним та вибір їх вочевидь дуже обмежений.

Математичні дисципліни.

Алгебра

\begin{tabular}{|c|c|c|}
\hline $\begin{array}{l}\text { Педагогічний програмний } \\
\text { «Алгебра, } 10 \text { клас» }\end{array}$ & $\begin{array}{l}\text { ДП «НВП } \\
\text { Укрприладсервіс» }\end{array}$ & $\begin{array}{l}\text { 2006, Рекомендовано } \\
\text { МОН України }\end{array}$ \\
\hline $\begin{array}{l}\text { Педагогічний програмний } \\
\text { «Алгебра, } 11 \text { клас» }\end{array}$ & $\begin{array}{l}\text { ДП "НВП } \\
\text { Укрприладсервіс }\end{array}$ & $\begin{array}{l}\text { 2006, Рекомендовано } \\
\text { МОН України }\end{array}$ \\
\hline $\begin{array}{l}\text { ний } \\
\text { ка }\end{array}$ & І ДПУ & $\begin{array}{l}\text { 2006, Рекомендовано } \\
\text { МОН України }\end{array}$ \\
\hline $\begin{array}{l}\text { середовище «Система } \\
\text { внянь» }\end{array}$ & $\mathrm{Xe}_{1}$ & $\begin{array}{l}\text { Лист від } 02.08 .0 \\
2671 \quad \text { Реком } \\
\text { МОН України }\end{array}$ \\
\hline Програмно-методичний & $\mathrm{ep}$ & Лист від 15.02.05, №1/11- \\
\hline
\end{tabular}


«ТЕРM VII» підтримки навчальної

657 Рекомендовано МОН

математичної діяльності України

Геометрія

\begin{tabular}{|c|c|c|}
\hline $\begin{array}{l}\text { Педагогічний } \quad \text { програмний } \\
\text { «Геометрія, } 10 \text { клас» }\end{array}$ & ЗАТ «Мальва» & $\begin{array}{l}\text { 2006, } \\
\text { МОН Уккраїни }\end{array}$ \\
\hline $\begin{array}{l}\text { Педагогічний } \\
\text { «Геометрія, } 11 \text { клас» }\end{array}$ & ЗАТ «Мальва» & \begin{tabular}{|l}
$2006, \quad$ Рекомендовано \\
МОН України
\end{tabular} \\
\hline $\begin{array}{l}\text { Педагогічний програмний засіб } \\
\text { «Бібліотека електронних наочностей } \\
\text { "Геометрія, 7-9"» }\end{array}$ & ЗАТ «Маль & $\begin{array}{l}\text { 2006, Рекомендовано МОН } \\
\text { України }\end{array}$ \\
\hline Пакет динамічної геометрії & $\begin{array}{l}\text { Харківський ДПУ } \\
\text { iм. Г.С.Сковороди }\end{array}$ & $\begin{array}{l}\text { Лист від 2002, } \\
\text { Рекомендовано } \\
\text { України }\end{array}$ \\
\hline $\begin{array}{l}\text { Програмно-методичний } \\
\text { «Математика, 5-6 класи" }\end{array}$ & ПП "Контур плюс" & $\begin{array}{l}\text { 2006, Рекомендовано МОН } \\
\text { України }\end{array}$ \\
\hline $\begin{array}{l}\text { Програмно-методичний } \\
\text { GRAN }\end{array}$ & $\begin{array}{ll}\text { TОВ "Респ. } & \text { навч.- } \\
\text { науковий } & \text { центр } \\
\text { "ДІНІТ" } & \end{array}$ & $\begin{array}{l}2002, \text { Рекомендовано МОН } \\
\text { України }\end{array}$ \\
\hline
\end{tabular}

Дещо ширше представлені ППЗ та НКП для предметів науково-природничого циклу для старших класів загальноосвітніх навчальних закладів.

Біологія

\begin{tabular}{|c|c|c|}
\hline $\begin{array}{l}\text { Програмно-методичний } \\
\text { "Біологія, } 10 \text { клас" }\end{array}$ & $\begin{array}{l}\text { ЗАТ " Транспортні } \\
\text { системи" }\end{array}$ & $\begin{array}{l}\text { 2006, Рекомендовано МОН } \\
\text { України }\end{array}$ \\
\hline $\begin{array}{l}\text { Програмно-педагогічний } \\
\text { "Віртуальна біологічна лабораторія, } \\
\text { 10-11 кл." }\end{array}$ & $\mathrm{AT} \ll \mathrm{CMIT} »$ & $\begin{array}{l}\text { Лист від 24.05.06, №1/11- } \\
2582 \text { Рекомендовано МОН } \\
\text { України }\end{array}$ \\
\hline $\begin{array}{l}\text { Педагогічний програмний засіб } \\
\text { «Бібліотека електронних наочностей } \\
\text { "Біологія,6-11 кл."» }\end{array}$ & $\begin{array}{l}\text { АТЗТ "Квазар } \\
\text { Мікро Техно" }\end{array}$ & \begin{tabular}{|lr} 
Лист \\
662 від 15.02 .05$, & №1/11- \\
Уекомендовано & МОН \\
України &
\end{tabular} \\
\hline $\begin{array}{l}\text { ий курс "Шкільний курс } 3 \\
1 \text { кл." }\end{array}$ & $\begin{array}{l}\text { НТУ } \\
\text { Київ }\end{array}$ & $\begin{array}{l}\text { Лист від 29.04.05, №1/11- } \\
2111 \text { Рекомендовано МОН } \\
\text { України }\end{array}$ \\
\hline к «Біоло & $\begin{array}{ll}\text { Ін-тут } & \text { проблем } \\
\text { штучного } & \\
\text { інтелекту } & \text { МОН } \\
\text { НАН } & \text { України } \\
\text { Донецьк } & \end{array}$ & $\begin{array}{l}\text { Лист НМЦ від } 10.11 .03 \\
\text { Схвалено МОН України }\end{array}$ \\
\hline $\begin{array}{l}\text { Віртуальна лабораторія } \\
\text { людини, 8-9» }\end{array}$ & $\begin{array}{l}\text { ЗАТ "Транспортні } \\
\text { системи" }\end{array}$ & $\begin{array}{l}\text { 2006, Рекомендовано I } \\
\text { України }\end{array}$ \\
\hline
\end{tabular}

Хімія

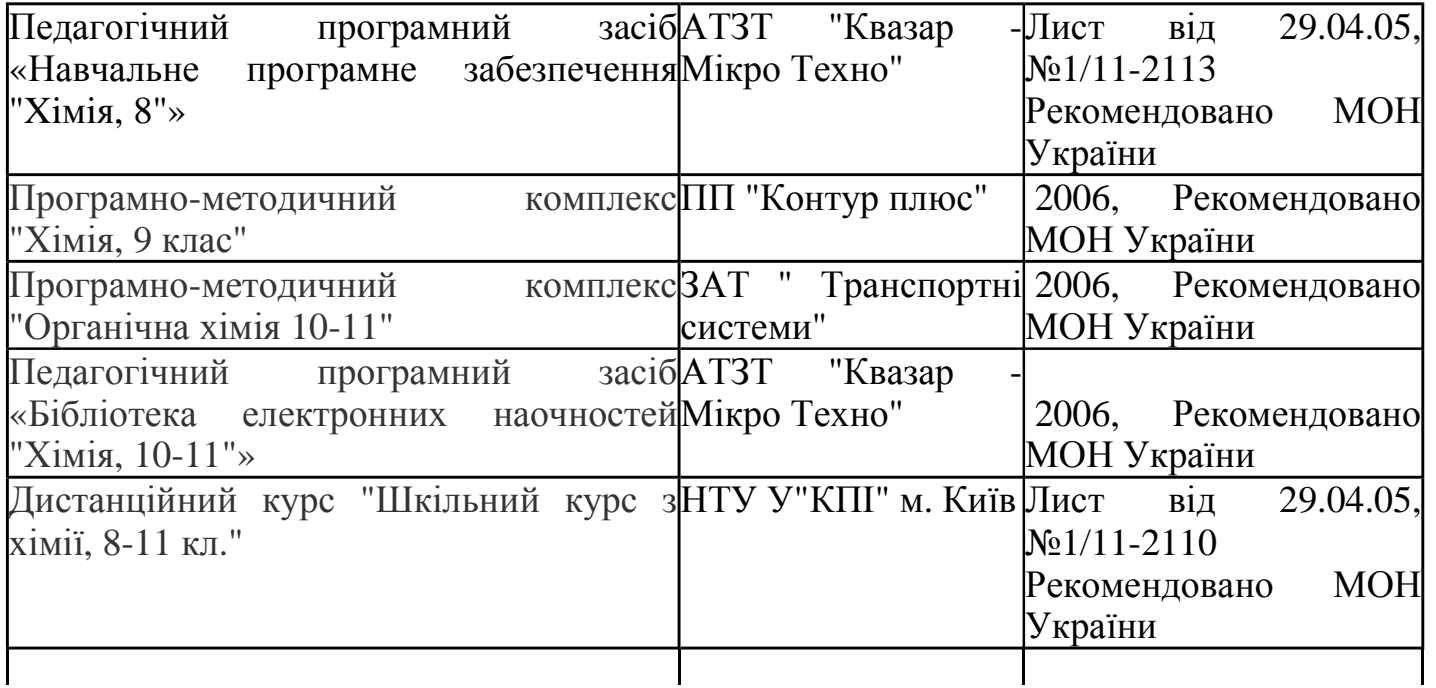




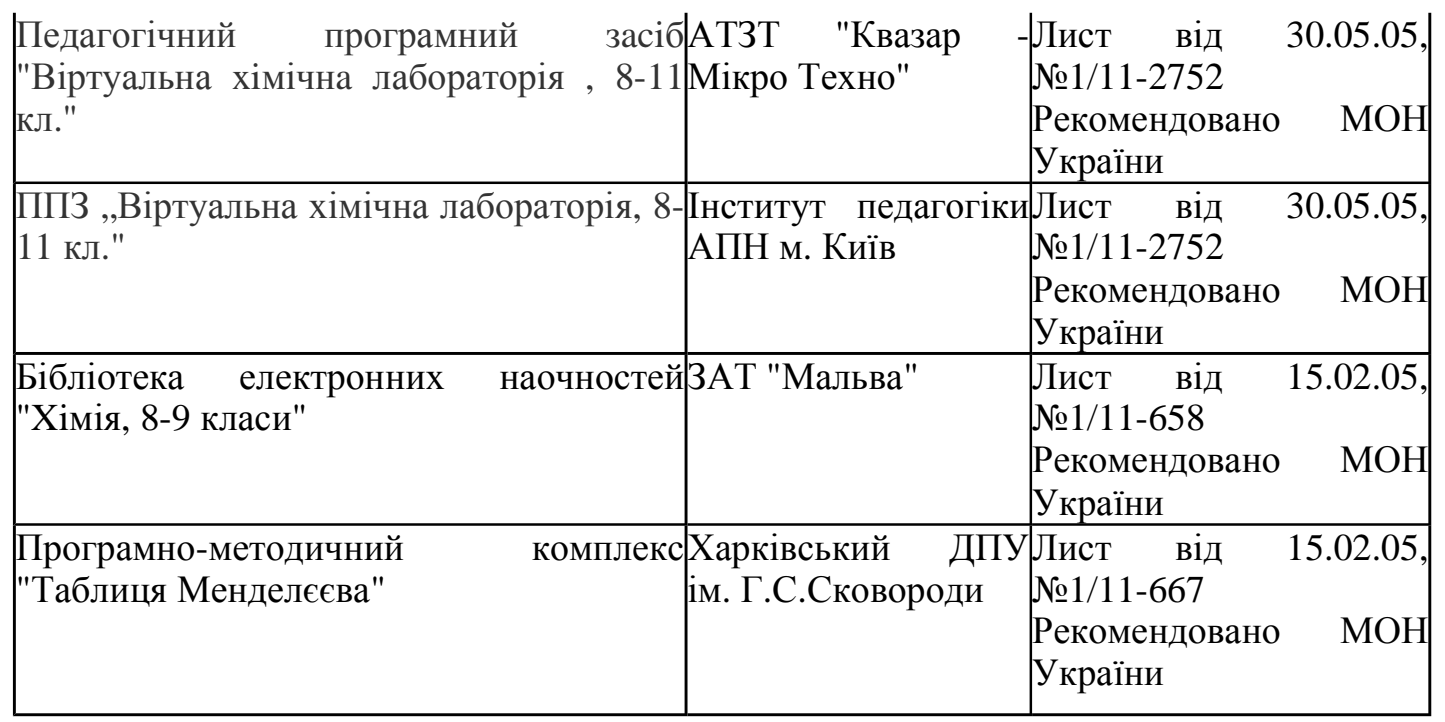

Фізика

\begin{tabular}{|c|c|}
\hline $\begin{array}{l}\text { Педагогічний } \\
\text { "Фізика-7" }\end{array}$ & \begin{tabular}{|l|l|} 
АТЗТ "Квазар - Мікро \\
Техно" \\
$\begin{array}{l}\text { Тист від 15.02.05, №1/11- } \\
\text { України }\end{array}$ \\
\end{tabular} \\
\hline $\begin{array}{l}\text { Педагогічний } \\
\text { "Фізика-8" }\end{array}$ & 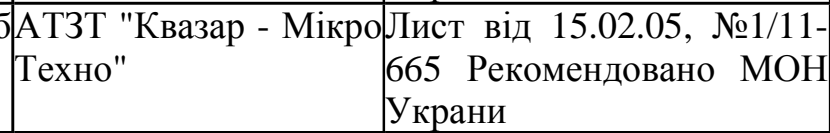 \\
\hline $\begin{array}{l}\text { Педагогічний } \\
\text { "Фізика-9" }\end{array}$ & \begin{tabular}{|l|l|} 
АТЗТ "Квазар - Мікро Лист від 15.02.05, №1/11- \\
Техно" \\
$\begin{array}{ll}660 \text { Рекомендовано МОН } \\
\text { Украни }\end{array}$
\end{tabular} \\
\hline $\begin{array}{l}\text { Педагогічний } \quad \text { програмний засіб } \\
\text { "Навчальне програмне забезпечення } \\
\text { фізики для } 10 \text { класу 3Н3" }\end{array}$ & \begin{tabular}{|l|l} 
АТЗТ "Квазар - Мікро Лист від 30.05.05, №1/11- \\
Техно" \\
2754 Рекомендовано МОН \\
України
\end{tabular} \\
\hline $\begin{array}{l}\text { Педагогічний програмний засіб } \\
\text { "Навчальне програмне забезпечення } \\
\text { фізики для } 11 \text { класу 3Н3" }\end{array}$ & $\begin{array}{l}\text { 3АТ " } \\
\text { системи" Транспортні| Лист від 30.05.05, №1/11- } \\
\\
2753 \text { Рекомендовано МОН } \\
\text { України }\end{array}$ \\
\hline 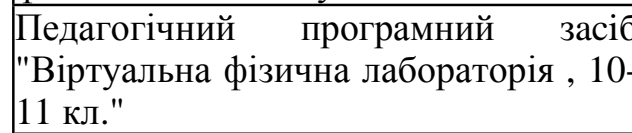 & \begin{tabular}{|l|l} 
АТЗТ "Квазар - Мікро \\
Техност від 15.02.05, №1/11- \\
$\begin{array}{l}\text { (Т72 Рекомендовано МОН } \\
\text { України }\end{array}$
\end{tabular} \\
\hline $\begin{array}{l}\text { Педагогічний програмний засіб } \\
\text { "Бібліотека електронних наочностей } \\
\text { "Фізика, 10-11 кл." }\end{array}$ & \begin{tabular}{|l|l|} 
АТЗТ "Квазар - Мікро & Лист від 22.03.05, №1/11- \\
& 1185 Рекомендовано МОН \\
України
\end{tabular} \\
\hline $\begin{array}{l}\text { Педагогічний програмний засіб } \\
\text { "Віртуальна фізична лабораторія , 7-9 } \\
\text { кл." }\end{array}$ & \begin{tabular}{|l|l|} 
АТЗТ "Квазар - Мікро Лист від 15.02.05, №1/11- \\
9 Техно" & $\begin{array}{l}663 \text { Рекомендовано МОН } \\
\text { України }\end{array}$
\end{tabular} \\
\hline $\begin{array}{l}\text { Педагогічний програмний засіб } \\
\text { «Бібліотека електронних наочностей } \\
\text { "Фізика, 7-9 кл."» }\end{array}$ & \begin{tabular}{|l|l} 
АТЗТ "Квазар - Мікро Лист від 15.02.05, №1/11- \\
Техно"
\end{tabular} \\
\hline $\begin{array}{lcc}\text { Педагогічний } & \text { програмний } & \text { засіб } \\
\text { "Електронний задачник "Фізика, 7-9" }\end{array}$ & \begin{tabular}{|l|l} 
АТЗТ "Квазар - Мікро Лист від 15.02.05, №1/11- \\
Техно" & $\begin{array}{l}\text { 1186 Рекомендовано МОН } \\
\text { України }\end{array}$
\end{tabular} \\
\hline $\begin{array}{l}\text { Педагогічні програмні засоби від } \\
\text { "Квазар-Мікро""'Віртуальна фізична } \\
\text { лабораторія } \\
\text { електронних наочностей", }\end{array}$ & \begin{tabular}{l|l|} 
АТЗТ "Квазар - Мікро & $\begin{array}{l}\text { 2006, } \\
\text { МОН України }\end{array}$ \\
(Техно"
\end{tabular} \\
\hline 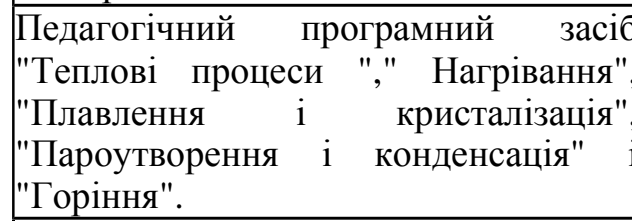 & $\begin{array}{l}\text { АТЗТ "Квазар } \\
\text { Мікро Техно" }\end{array}$ \\
\hline $\begin{array}{ll}\text { Цикл } & \text { Відеофільмів } \\
\text { "Channel" } & \text { енциклопе } \\
\end{array}$ & $\begin{array}{l}\text { ООО "Візит", } \\
\text { м. Дніпропетровськ }\end{array}$ \\
\hline
\end{tabular}




\begin{tabular}{|c|c|c|}
\hline & & України \\
\hline Електронна енциклопедія & $\begin{array}{l}\text { ООО "Візит", } \\
\text { м. Дніпропетровськ }\end{array}$ & \begin{tabular}{|lrr} 
Лист НМЦ & від 16.11 .05 \\
№1/11-66836 & Схвалено \\
МОН України &
\end{tabular} \\
\hline
\end{tabular}

Найбільш поширені розробки ППЗ з історії України та Всесвітньої історії для старших класів загальноосвітньої школи.

\begin{tabular}{|c|c|c|c|}
\hline $\begin{array}{l}\text { Електронний атлас з історії України, } \\
5 \text { клас }\end{array}$ & \multicolumn{2}{|c|}{$\begin{array}{l}\text { ЗАТ «Інститут } \\
\text { перед. технологій» }\end{array}$} & Схвалено МОН України \\
\hline $\begin{array}{l}\text { Педагогічний програмний засіб "Світ } \\
\text { античної культури, } 6 \text { клас" }\end{array}$ & \multicolumn{2}{|c|}{ ПП «Контур плюс» } & $\begin{array}{l}\text { 2006, Рекомендовано МОН } \\
\text { України }\end{array}$ \\
\hline $\begin{array}{l}\text { Педагогічний програмний засіб } \\
\text { "Електронний атлас для курсу } \\
\text { історії України, } 7 \text { клас". }\end{array}$ & \begin{tabular}{r|l} 
iб & ЗАТ «Інст1 \\
3 & передових \\
& технологій»
\end{tabular} & & $\begin{array}{l}\text { Лист НМЦ від 27.0 } \\
\text { №1.11-2718 Схвалено } \\
\text { України }\end{array}$ \\
\hline $\begin{array}{l}\text { Педагогічний програмний засіб } \\
\text { "Електронний атлас для курсу з } \\
\text { всесвітньої історії, } 8 \text { кл." }\end{array}$ & $\begin{array}{l}\text { ЗАТ «Інститут } \\
\text { передових } \\
\text { технологій» }\end{array}$ & \multicolumn{2}{|c|}{$\begin{array}{l}\text { Лист від 15.02.05, №1/11- } \\
654 \text { Рекомендовано МОН } \\
\text { України }\end{array}$} \\
\hline $\begin{array}{l}\text { Педагопчний програмний засіб " } \\
\text { Електронний атлас для курсу з } \\
\text { історії" України, } 8 \text { кл." }\end{array}$ & $\begin{array}{l}\text { ЗАТ «Інститут } \\
\text { передових } \\
\text { технологій» }\end{array}$ & \multicolumn{2}{|c|}{$\begin{array}{l}\text { Лист від 29.04.05, №1/11- } \\
2112 \text { Рекомендовано МОН } \\
\text { України }\end{array}$} \\
\hline $\begin{array}{l}\text { Педагогічний програмний засіб } \\
\text { "Культура доби відродження, } 8 \\
\text { клас" }\end{array}$ & ПП "Контур плюс" & \multicolumn{2}{|c|}{$\begin{array}{l}\text { 2006, Рекомендовано МОН } \\
\text { України }\end{array}$} \\
\hline $\begin{array}{l}\text { Педагогічний програмний засіб } \\
\text { "Історія України для } 9 \text { класу" }\end{array}$ & $\begin{array}{l}\text { TOB "Компанія } \\
\text { "Дієз-продукт" }\end{array}$ & \multicolumn{2}{|c|}{\begin{tabular}{|l|} 
Лист НМЦ від 29.12.04, \\
№1039 Схвалено ЗН і НМР \\
питань освіти МОН України \\
\end{tabular}} \\
\hline $\begin{array}{l}\text { Педагогічний програмний } \\
\text { засіб"Електронний атлас для курсу з } \\
\text { всесвітньої історії", } 9 \text { кл. }\end{array}$ & $\begin{array}{l}\text { ЗАТ«Інститут } \\
\text { передових } \\
\text { технологій» }\end{array}$ & \multicolumn{2}{|c|}{$\begin{array}{l}\text { Лист від 02.06.05, №1/11- } \\
2857 \text { Рекомендовано МОН } \\
\text { України }\end{array}$} \\
\hline $\begin{array}{l}\text { Педагогічний програмний засіб. } \\
\text { Історія України із середини XVIII до } \\
\text { XX століття. }\end{array}$ & $\begin{array}{l}\text { TОВ "Компанія } \\
\text { "Дієз-продукт" }\end{array}$ & \multicolumn{2}{|c|}{$\begin{array}{l}\text { Рекомендовано МОН } \\
\text { України }\end{array}$} \\
\hline \begin{tabular}{|l|} 
Педагогічний програмний засіб \\
"Історія України, 9 клас"
\end{tabular} & ПП "Контур плюс" & \multicolumn{2}{|c|}{$\begin{array}{l}\text { 2006, Рекомендовано МОН } \\
\text { України }\end{array}$} \\
\hline $\begin{array}{l}\text { Педагогічний програмний засіб } \\
\text { "ІІнтегрований електронний } \\
\text { комплекс "Всесвітня історія, } 10 \text { клас }\end{array}$ & ТОВ "АВТ лтд." & \multicolumn{2}{|c|}{$\begin{array}{l}\text { Лист від 15.02.05, №1/11- } \\
655 \text { Рекомендовано МОН } \\
\text { України }\end{array}$} \\
\hline $\begin{array}{l}\text { ППЗ "Електронний атлас з курсу } \\
\text { "Історії України, } 10 \text { кл." для ЗНЗ" }\end{array}$ & $\begin{array}{l}\text { 3АТ «Інститут } \\
\text { передових } \\
\text { технологій» }\end{array}$ & \multicolumn{2}{|c|}{$\begin{array}{l}\text { Лист від 07.03.06, №1/11- } \\
974 \text { Рекомендовано МОН } \\
\text { України }\end{array}$} \\
\hline $\begin{array}{l}\text { Педагогічний програмний засіб } \\
\text { "Всесвітня історія. Новітня історія } \\
\text { 1939-2003" для } 11 \text { класу }\end{array}$ & $\begin{array}{l}\text { TOB "Компанія } \\
\text { "Дієз-продукт" }\end{array}$ & \multicolumn{2}{|c|}{$\begin{array}{l}\text { Лист від 14.01.04, №1/2-98 } \\
\text { Рекомендовано МОН } \\
\text { України }\end{array}$} \\
\hline $\begin{array}{l}\text { Педагогічний програмний засіб } \\
\text { "Електронний атлас з Нової історії } \\
\text { (1789-1914 рр.) для } 11 \text { класу }\end{array}$ & $\begin{array}{l}\text { ЗАТ «Інститут } \\
\text { передових } \\
\text { технологій» }\end{array}$ & \multicolumn{2}{|c|}{$\begin{array}{l}\text { Лист НМЦ від 29.06.04, } \\
\text { №441 Схвалено комісією 3Н } \\
\text { та шкільного обладнання } \\
\text { НМР з питань освіти МОН } \\
\text { України }\end{array}$} \\
\hline $\begin{array}{l}\text { Педагогічний програмний засіб } \\
\text { "Новітня історія України" для } 11 \\
\text { класу }\end{array}$ & $\begin{array}{l}\text { TOB "Компанія } \\
\text { "Дієз-продукт" }\end{array}$ & \multicolumn{2}{|c|}{$\begin{array}{l}\text { Лист від 14.03.05, №1/11- } \\
1015 \text { Рекомендовано МОН } \\
\text { України }\end{array}$} \\
\hline $\begin{array}{l}\text { Педагогічний програмний засіб } \\
\text { "Електронний атлас з історії Україниг } \\
\text { (1939-2005pp.) для } 11 \text { класу ЗНЗ". }\end{array}$ & $\begin{array}{l}\text { 3АТ «Інститут } \\
\text { передових } \\
\text { технологій» }\end{array}$ & \multicolumn{2}{|c|}{$\begin{array}{l}\text { Лист від 12.07.05, №1/11- } \\
664 \text { Рекомендовано МОН } \\
\text { України }\end{array}$} \\
\hline $\begin{array}{l}\text { Педагогічний програмний засіб } \\
\text { "Новітня історія, } 11 \text { клас" }\end{array}$ & ПП "Контур плюс" & \multicolumn{2}{|c|}{$\begin{array}{l}\text { 2006, Рекомендовано МОН } \\
\text { України }\end{array}$} \\
\hline Педагогічний програмний зас & $\begin{array}{l}\text { Інститут проблем } \\
\text { шт. ін тел. МОН і } \\
\text { НАН України м. }\end{array}$ & \multicolumn{2}{|c|}{ Лист НМЦ від 10.11.03 } \\
\hline
\end{tabular}




\begin{tabular}{|l|l|l|}
$\mid$ Міфи народів світу" & Донецьк & Схвалено МОН України \\
\hline Дистанційний курс "Історія України, & НТУ У"КПІ" м. Київ & 2006, Рекомендовано МОН \\
\hline $7-11$ класи" & & України \\
\hline
\end{tabular}

чином, у межах цієї статті немає

можливості розглянути всі питання, які характеризують вимоги до ППЗ та їх стан в українській освіті. Але можна зазначити, що процес подальшого впровадження засобів ІКТ в навчально-виховний процес освітніх закладів України потребує створення системи розробки ППЗ, у межах якої необхідно здійснити комплексні дослідження психолого-педагогічного та методичного спрямування, результатом яких мають стати рекомендації щодо організації науково-виробничого процесу створення засобів ІКТ навчального призначення [8].

Бажано збільшити асортимент ППЗ навіть 3 однієї теми 3 того чи іншого предмету, які б відрізнялися не змістом чи послідовністю викладення матеріалу, а стилем викладу та використанням різних методів і форм, що реалізовані засобами сучасних інформаційно-комунікаційних технологій. Лише так у галузі освіти можна створити конкурентне середовище навчальних комп'ютерних програм та програмно педагогічних засобів навчання.

Як показує практика, програмне забезпечення розповсюджується переважно стихійно і не узаконеним способом. Майже відсутній фонд алгоритмів і програм накопичення i тиражування ліцензованого програмного забезпеченням як загальноосвітнього, так і спеціального призначення, періодичними фаховими виданнями для вчителів та учнів.

Практично відсутне комп'ютерно-орієнтоване науково-методичне забезпечення 3 деяких предметів базового навчального плану середньої освіти, що не сприяє комп'ютерній підтримці навчального процесу. Навчальні програми мають містити перелік легально поширюваних програмних засобів, які використовуються в навчальному процесі.

Потрібно ширше залучати вчителів-практиків до створення, апробації та рецензування навчальних педагогічних програмних засобів.

Таким чином, тільки у разі налагодження державного підходу у вирішенні цілої низки вище указаних питань, можна створити такі програмно-методичні комплексні розробки, які б забезпечили ефективне ведення навчального процесу в цілому, підтримуючи взаємодію вчителя та учня, а також забезпечували б усі аспекти навчання - від подання нового матеріалу, підтримки практичної роботи, перевірки знань учня до розширення і поглиблення його знань та умінь.

\section{Список використаних джерел}

1. Бронштейн E.M., Гареева Л.Р., Закирова Г.Ф. Пакет обучающих программ по школьной стереометрии // Материалы научно-технической конференции "Новые информационные технологии в университетском образовании". - Новосибирск: НГУ, - 1996. - 300 с.

2. Козлов O.A., Солодова E.A., Холодоз E.H. Некоторые аспекты создания и применения компьютеризированного учебника // Информатика и образование. - 1995. - № 3. - С. 97-99.

3. Моргун О.М., Підласий А.I. Комп'ютерний підручник як новий дидактичний засіб // Педагогіка і психологія. - 1994. - № 1. - С. 117-124.

4. Машбии Е.И. Психолого-педагогические проблемы компьютеризации обучения: (Педагогическая наука - реформе школы). - М.: Педагогика, 1988. - 192 с.

5. Евреинов Э.В., Каймин В.А. Информатика и дистанционное образование. - М.: "ВАК", 1998. $88 \mathrm{c}$.

6. Ільён B.B. Дидактичні та технологічні вимоги до програми-оболонки для підготовки та використання електронних навчальних посібників. [Електронний ресурс] Науково-методичного центру 
аграрної освіти / С.М. Бойко/ «Аграрна освіта» (Луганськ, 4 грудня 2003 р.) - Режим доступу: http://www.sau.sumy.ua/elbooks/EL_POS.doc. - Заголовок з екрана.

7. Жук Ю. О., Соколюк О.М. Педагогічні програмні засоби як ринковий продукт. Електронний каталог Наукової бібліотеки НПУ. - [Електронний ресурс]. - Режим доступу:www.hklib.npu.edu.ua/cgibin/irbis64r_71/cgiirbis_64.exe?C21COM=.

8. Основи нових інформаційних технологій навчання: Посібник для вчителів / Авт. кол.; За ред. Ю.І. Машбиця / Інститут психології ім. Г.С. Костюка АПН України. - К.: ІЗМН, 1997. - 264 с.

9. «Про затвердження Державного стандарту базової і повної загальної середньої освіти» Постанова Кабінету Міністрів України від 14 січня 2004 р. №24 [№24, 14.01.2004, Постанова, Стандарт, Кабінет Міністрів України

Про затвердження Державного стандарту базової і повної загальної середньої освіти] [Електронний pecypc]. - Режим доступу: - http://zakon.nau.ua/doc/?uid=1053.24.0.

10. Жук Ю.О. Вплив ІКТ на формування особистості школярів / Інформатика. - № 9(201), березень 2003 p. - С. 3-5.

\section{ОСНОВНЫЕ ТРЕБОВАНИЯ К УЧЕБНЫМ КОМПЬЮТЕРНЫМ ПРОГРАММАМ В БАЗОВОМ СРЕДНЕМ ОБРАЗОВАНИИ \\ Савченко 3.В. \\ Аннотация}

Статья посвящена актуальным вопросам эффективности использования учебных компьютерных программ (УКП) в компьютерно ориентированной учебной среде, указаны основные требования к ним и дан перечень сертифицированных разработок УКП из естественных предметов, которые можно рекомендовать для базового среднего образования.

Ключевые слова: учебные компьютерные программы, педагогические программные средства, сертифицированные программные разработки.

\section{THE MAIN REQUIREMENTS TO EDUCATIONAL SOFTWARE FOR THE BASE SECONDARY EDUCATION}

\section{Savchenko Z.}

\section{Resume}

The article deals with the efficiency of educational computer programs (ECP) use in the computer based educational environment, the basic requirements to them as well as the list of certificated developments of ECP for science subjects, which can be recommended for the base secondary education.

Keywords: educational computer programs, pedagogical software, certificated program developments. 